\title{
Properties of Soils and Plants Uptake within the Vicinity of Selected Automobile Workshops in Ile-Ife Southwestern, Nigeria Adewole M.B.* and Uchegbu L. U.
}

\begin{abstract}
Backyard farming is becoming popular among the auto mechanics near their workshops where spent engine oil and carcass of vehicles are continuously dumped in Nigeria. The properties of soil and maize plants sampled from the vicinity of selected auto mechanic workshops in Ile-Ife, Nigeria were investigated. The results showed that heavy metal contents in the soils from the sampled sites were (range, $\mathrm{mg} \mathrm{kg}^{-1}$ ) Fe 1238.12 to $1564.25, \mathrm{Zn}$ 18.10 to $24.75, P b 1.21$ to 3.43 and $\mathrm{Hg} 0.48$ to 0.74 . These values were significantly $(P<0.05)$ higher than the control (non auto mechanic site) with Fe 37.50, $\mathrm{Zn} \mathrm{0.70,Pb} 0.15$ and $\mathrm{Hg} 0.13 \mathrm{mg} \mathrm{kg}^{-1}$. Also, these soil parameters reduced in values in the sub-soil. The mean concentrations of heavy metals ( $\mathrm{Fe}, \mathrm{Zn}, \mathrm{Pb}$ and $\mathrm{Hg}$ ) in maize plants were significantly $(P<0.05)$ higher while $N$ and $P$ were significantly $(P<0.05)$ lower in those from the experimental sites within the vicinity of automobile workshops than in the control. Higher accumulation of these heavy metals was obtained in soil and shoots of maize from older workshops than in the younger ones. The study therefore concluded that edible crops, particularly the phytoplants should not be cultivated on polluted soils as this may pose a threat to human health, if the heavy metals enter the food chain.
\end{abstract}

Keywords: Backyard farming, automobile, spent engine oil, carcass of vehicle, plant uptake, phytoplant.

\section{Introduction}

Pollution of soil ecosystem is the introduction of excessive amount of substances which impair the health of living organisms or interfere with the legitimate use of the soil environment. Pollution of the soil ecosystem is a major source of soil degradation (Mbagwu, 2008). Soil ecosystem is an essential component of life and man depends on it for food and natural resources while plants depend on it for their growth. It is also a medium for the biochemical cycling of soil nutrients. So, as the soil is being contaminated with all manner of pollutants, the life process is being disturbed and hence there may be imbalance in the whole system.

Wide varieties of wastes generated from human activities are dumped on soil (Adeoye et al., 2005). Soils have long being used as dump sites for household and commercial wastes (Uchegbu, 2008). Wastes containing heavy metals; if disposed on agricultural soils or around residential areas can enter into the food chain (Ademoroti, 1996). Animals that forage on the vegetation of the heavy metals polluted soils are also in danger. Soils affected by heavy metals suffer degradation due to impairment of physicochemical, biological and mineralogical properties; hence undermine its agricultural potential (Mbagwu, 2008).

Presently in Nigeria, one of the major sources of increase in heavy metals concentration of the soil ecosystem is auto mechanic activities (Odjegba and Sadiq, 2002). During activities like overhauling of vehicle engines, metal fabrication and automobile panel beating, reasonable amount of spent engine oil and metal fillings are deposited on top soil (Uchegbu, 2008). Painting of vehicles and tyre vulcanizing are other activities that negatively affect the qualities of soils around automobile workshops.

Soils polluted with spent engine oil had reduced soil microbial activity and reduced soil fertility status (McGrath et al., 1995). Heavy metal toxicity and insufficient soil aeration to growing plants are associated problems to soil polluted with spent engine oil (Anoliefo and Vwioko, 1995). Spent engine oil runoff indirectly increases the native concentrations of some heavy metals. The growing crops take-up these heavy metals and thereafter transport them to different parts of the plants (Adewole, 2006). The degraded soil leads to low crop yield (Rainbow, 2007) and reduced crop quality (Adeoye et al., 2005). Unfortunately, many of the available soils near these workshops are being cultivated, particularly with maize, cassava and vegetables.

Apart from the fact that many of these crops have ability to remove these inorganic chemicals, especially the heavy metals from the soil and store them in different parts of the plants (Adewole et al., 2008), they are also dangerous to human health, if ingested (Pirkle et al., 1998). Ademoroti (1996) worked on okro and bitter leaf and reported the appreciable concentrations of heavy metals removed and stored by these crops when they were planted on contaminated soils.

Backyard farming in the immediate vicinity of the automobile workshops is 
increasing in Nigeria. These mechanics engaged in this farming exercise whenever they have no auto-repair work to do. Currently, there is a dearth of information on the quality of soils and cultivated crops in the vicinity of automobile workshops in the humid tropics of Africa. The experiment therefore aims at providing information on the quality of soils as affected by human activities around some selected auto-mechanic workshops and the bioaccumulation of selected heavy metals in the shoots of maize plant.

\section{Materials and Methods}

\section{Experimental site identification}

The study area, Ile-Ife, lies within latitude $07^{\circ} 28.00^{\prime}$ and $07^{\circ} 30.03^{\prime} \mathrm{N}$ longitude $004^{\circ} 32.00^{\prime}$ and $004^{\circ} 34.23^{\prime} \mathrm{E}$ with elevation range of 260-300 $\mathrm{m}$ above the sea level in Ife Central Local Government Area of Osun State. It falls within the tropical forest of southwestern Nigeria (LRS, 1976) and of the basement complex soil origin. The rainfall pattern is bimodal and falls from late March to late November each year. Preliminary survey was carried out to identify auto-mechanic workshops whose surrounding vacant lands were being cultivated with edible crops in April 2008. From the eight auto mechanic workshops identified, out of a total of fifteen in Modakeke, Ile-Ife, only three were randomly selected $(37.5 \%$ of the auto mechanic whose surrounding vacant land are cropped) and a control location (non-auto mechanic workshop) were used as experimental sites.

The workshops were in different locations and were established at different times, viz: Oke-Ayo (12 years ago), Ajebandele ( 9 years ago) and Modakeke (17 years ago). These workshops still function till now. Maize (yellow maize) grains purchased from the local markets were planted on the vacant land near each of the auto mechanic workshops and the control site $(65 \mathrm{~m}$ away from a mechanic workshop) by these mechanics. Each of the established plot size was $4 \times 6 \mathrm{~m}^{2}$, including the control plot, mapped out from the mechanic farms. No soil amendments were applied.

\section{Soil sampling and sample analyses}

From each of the experimental plots, including the control, four composite soil samples each to the depths $0-15 \mathrm{~cm}$ and $15-30$ $\mathrm{cm}$ were taken using simple random technique to give a total of 32 soil samples were collected. The samples were air-dried for 7 days to stop all microbial activities and passed through $2 \mathrm{~mm}$ sieve for pre-soil test physicochemical analyses. Soil analyses carried out included: Soil $\mathrm{pH}$ using a $\mathrm{pH}$ meter in 1:1 soil$\mathrm{H}_{2} \mathrm{O}$ suspension (Mclean, 1982), particle size analysis by hydrometer method and Total nitrogen by macro Kjeldahl apparatus. Others are: available phosphorus by Bray's I method (Black, 1965), organic carbon using WalkleyBlack wet oxidation method (Nelson and Sommers, 1982), micro nutrients (Fe and $\mathrm{Zn}$ ) extracted using 0.1M HCl (Juo, 1982) and extractible heavy metals $(\mathrm{Hg}$ and $\mathrm{Pb})$ using mixture of conc. $\mathrm{HNO}_{3}$ and Conc. $\mathrm{HClO}_{4}$ in the ratio 2:1 with Conc. $\mathrm{H}_{2} \mathrm{SO}_{4}$ (Odu et al., 1986). The concentrations of $\mathrm{Fe}, \mathrm{Zn}, \mathrm{Hg}$ and $\mathrm{Pb}$ in the soil extracts were read on Atomic Absorption Spectrophotometer (AAS) PerkinElmer Model 403.

\section{Plant sampling and sample analyses}

With a clean razor blade, four representative samples of maize plant shoots from each experimental site were taken at six Weeks After Planting (WAP) to give a total of sixteen samples. The plant samples were thoroughly washed with de-ionized water dried in an oven for 48 hours at $70^{\circ} \mathrm{C}$, weighed, ground and analyzed for nutrients and heavy metals uptake. Analyses on plant samples carried out included: Total nitrogen by micro Kjeldahl apparatus, phosphorus using vanado molybdate yellow complex formation (Juo, 1982), concentrations of $\mathrm{Fe}$ and $\mathrm{Zn}$ using mixture of Conc. $\mathrm{HNO}_{3}$ and conc. $\mathrm{HClO}_{4}$ in the ratio $2: 1$ to digest the samples and heavy metals $(\mathrm{Hg}$ and $\mathrm{Pb})$ using mixture of Conc. $\mathrm{HNO}_{3}$ and Conc. $\mathrm{HClO}_{4}$ in the ratio 2:1 with 5 $\mathrm{ml}$ of Conc. $\mathrm{H}_{2} \mathrm{SO}_{4}$ were used (Odu et al., 1986). The concentrations of $\mathrm{Fe}, \mathrm{Zn}, \mathrm{Hg}$ and $\mathrm{Pb}$ in the plant extracts were read on AAS. The data were subjected to analysis of variance and Duncan Multiple Range Test was used to separate the means that were significant.

\section{Results and Discussion}

\section{Properties of the topsoil of the automobile workshop area}

Table 1 (a and b) showed the characteristics of soils of the four experimental locations. The soils were sandy clay loam. The mean soil $\mathrm{pH}$ ranged from 7.2 to 8.3, indicating a relatively neutral to slightly alkaline. The control soil had mean soil $\mathrm{pH}$ of 6.8 which was slightly acidic, typical of humid tropical soils (Kang, 1993). Total nitrogen (0.35 to $\left.0.86 \mathrm{~g} \mathrm{~kg}^{-1}\right)$, organic carbon (10.48 $\left.18.96 \mathrm{~g} \mathrm{~kg}^{-1}\right)$ and $\mathrm{P}\left(9.3415 .74 \mathrm{cmol} \mathrm{kg} \mathrm{kg}^{-1}\right)$ 
values obtained were respectively in the medium, high, and high ratings of soil fertility classes of soils in Nigeria (FMANR, 1990) despite the anthropogenic activities in the vicinities of the farm locations.

Also, the selected heavy metal concentrations were (range, $\mathrm{mg} \mathrm{kg}^{-1}$ ) $\mathrm{Fe}$ 1238.12 to 1564.24 , $\mathrm{Zn} 18.10$ to $24.75, \mathrm{~Pb}$ 1.21 to 3.43 and $\mathrm{Hg} 0.48$ to 0.74 ; which were significantly $(\mathrm{P}<0.05)$ higher than the control soil values which were: $\mathrm{Fe} 37.50, \mathrm{Zn} 0.70, \mathrm{~Pb}$ 0.15 and $\mathrm{Hg} 0.13 \mathrm{mg} \mathrm{kg}^{-1}$. These significant differences suggested soil contamination. $\mathrm{Fe}$ and $\mathrm{Zn}$ are plant micro-nutrients which are needed for good physiological plant growth in small amount (Banjoko, 1979) but have been grossly increased due to improper disposal of spent engine oil and carcass of motor vehicles. However, $\mathrm{Pb}$ and $\mathrm{Hg}$ concentrations have also increased mildly over the years. There were indications that the older the automobile workshop, the higher were the values of $\mathrm{Fe}$, $\mathrm{Zn}, \mathrm{Pb}$ and $\mathrm{Hg}$ possibly due to the longer period of deposition of spent engine oil and motor vehicle carcass on the nearby open vacant land.

\section{Properties of the sub-soil of the automobile workshop area}

Most of the soil properties reduced in concentrations down the soil profile, though with varied rates of reduction. Table 2 (a and b) showed the range of Total nitrogen ( 0.20 to $\left.0.53 \mathrm{~g} \mathrm{~kg}^{-1}\right), \mathrm{P}\left(9.36\right.$ to $\left.15.96 \mathrm{cmol} \mathrm{kg}^{-1}\right)$ and $\mathrm{K}$ ( 0.03 to $0.26 \mathrm{mg} \mathrm{kg}^{-1}$ ) while heavy metal contents of the sub-soil (range, $\mathrm{mg} \mathrm{kg}^{-1}$ ) $\mathrm{Fe}$ 982.55 to $1002.37, \mathrm{Zn} 13.55$ to $23.25, \mathrm{~Pb} 0.85$ to 2.66 and $\mathrm{Hg} 0.43$ to 0.68 . These values were significantly $(\mathrm{P}<0.05)$ higher than the control which was: $\mathrm{Fe} 3.57, \mathrm{Zn} 0.56, \mathrm{~Pb} 0.12$ and $\mathrm{Hg}$ $0.12 \mathrm{mg} \mathrm{kg}^{-1}$.

\section{Concentrations of $\mathrm{N}, \mathrm{P}$ and some heavy metals in the shoots of maize plant}

Table 3 showed the nutrients uptake in the maize shoots from the 4 locations. The mean concentrations of $\mathrm{N}, \mathrm{P}$ and some heavy metals in the shoots of maize plant samples were: $\mathrm{N} 2.33-2.64 \mathrm{~g} \mathrm{~kg}^{-1}, \mathrm{P} 0.24-0.30 \mathrm{cmol}$ $\mathrm{kg}^{-1}$, while others (range, $\mathrm{mg} \mathrm{kg}^{-1}$ ) $\mathrm{P} 0.24$ to $0.30, \mathrm{Fe} 126.56$ to $179.03, \mathrm{Zn} 11.51$ to 14.83 , $\mathrm{Pb} 0.43$ to 2.17 and $\mathrm{Hg} 0.20$ to 0.46 . These values were significantly $(\mathrm{P}<0.05)$ higher than the control values which were $\left(\mathrm{mg} \mathrm{kg}^{-1}\right)$ $\mathrm{Fe} 23.69, \mathrm{Zn} \mathrm{1.47,} \mathrm{Pb} 0.10$ and $\mathrm{Hg} 0.05$. The $\mathrm{N}$ and $\mathrm{P}$ values were, however, significantly $(\mathrm{P}<$ $0.05)$ lower in the contaminated soils of the automobile workshops than the control. The high concentrations of these heavy metals were as a result of improper disposal of spent engine oil generated and deposits of rusted iron from carcass of vehicles from the auto mechanic workshops. Adewole et al. (2009) reported that when these plant nutrients, including heavy metals are taking up by plants with theirs roots; they are transported to various parts of the plants.

Age of the service station played significant role also as the oldest of them (Modakeke station) had significantly $(\mathrm{P}<$ 0.05 ) highest mean concentrations of $\mathrm{Fe}, \mathrm{Zn}$, $\mathrm{Pb}$ and $\mathrm{Hg}$ in the plant samples at 6 WAP. However, this increase did not cut across board as the Oke-Ayo station which was the second oldest only had $\mathrm{Zn}$ and $\mathrm{Pb}$ mean concentration values next to Modakeke station. The workshop station at Ajebandele established 9 years ago had mean concentration values of $\mathrm{Fe}, \mathrm{Pb}$ and $\mathrm{Hg}$ next to Modakeke. This may not be unconnected with different volumes of servicing and repair works being carried out in these workshops and the records of which are not being kept by any of them.

\section{Conclusion}

The oldest automobile workshop had the highest accumulation of $\mathrm{Fe}>\mathrm{Zn}>\mathrm{Pb}>\mathrm{Hg}$, in that order, when compared with the youngest. The control site (none-automobile workshop) had metal concentrations typical of agricultural soils. It is therefore recommended that any attempt to cultivate an open vacant land near automobile workshops to edible crops, especially maize should be discouraged. These heavy metals, if ingested may affect the health of man (Pirkle et al., 1998). 


\section{References}

Adeoye G. O., Sridhar M. K. C., AdeOluwa O. O. and Akinsoji N. A. 2005. Evaluation of naturally decomposed solid wastes from municipal dumpsites for their manurial value in Southwest Nigeria. Journal of Sustainable Agriculture. 26(4): 142-152.

Ademoroti C. M. A. 1996. Environmental Chemistry and Toxicology, 1st ed. Foludex Press Ltd., Ibadan, Nigeria. 215 pp.

Adewole M. B. 2006. Phytoremediation of contaminated soils with some heavy metal using Helianthus annuus L. and Tithonia diversifolia (Hemsl) as influenced by fertilizer applications. Ph.D. Thesis. Department of Agronomy, University of Ibadan, Ibadan Nigeria. 149 pp.

Adewole M. B., Adeoye G. O., and Sridhar M. K. C. 2009. Effect of inorganic and organomineral fertilizers on the uptake of selected heavy metals by Helianthus annuus L. and Tithonia diversifolia (Hemsl.) under greenhouse conditions. Toxicological \& Environmental Chemistry. 91(5): 963-970. Anoliefo G.O.and Vwioko D.E. 1995. Effect of spent lubricating oil on the growth of Capsicum annuus L. and Lycopersicon esculentum Mill. Environmental

Pollution 88: 361-364.

Bang B.T. 1993. Changes in soil chemical properties and crop performance with continuous cropping on an Entisol in the humid tropics. In: K. Mulongoy and R. Merckx (eds.). Soil organic matter dynamics and sustainability of tropical agriculture. Proceedings of an International Symposium Organized by the Laboratory of Soil Fertility and Soil Biology, Katholieke Universiteit Leuven (K.U. Leuven) and the International Institute of Tropical Agriculture (IITA) held on November 4-6, 1991, Leuven, Belgium. pp. 297-305.

Federal Ministry of Agriculture and Natural Resources (FMANR). 1990. Literature review on soil fertility investigations in Nigeria. Bobma publishers, Ibadan, Nigeria. $281 \mathrm{pp}$.

Juo A.S.R. 1982. Automated and Semi automated methods for soil and plant analysis Manual series No. 7. Published and Printed by International Institute of Tropical Agriculture (IITA), Ibadan, Nigeria. 33 pp.
LRS (Land Resource Study). 1976. Soils of the Western State Savanna in Nigeria. Volume 1. The Environment. Land Resources Division, Ministry of Overseas Development, Tolworth Tower, England. 185 pp.

McGrath. S, Chaudri A.M.and Griller KE. 1995. Long term effects of metals in sewage sludge on soils, micro-organisms and plants. $J$. of Ind. Microbiology 14: 94-104.

Mclean E.O. 1982. Soil pH and lime requirement. In Methods of Soil Analysis. $2^{\text {nd }}$ ed., Part 2 ed., A. L. Page, R. H. Miller, and D. R. Keeney. eds. pp 595-624. Agronomy Monograph No. 9. Madison, WI: American Society of Agronomy.

Nelson D.W. and Sommers L.E. 1982. Total carbon, organic carbon and organic matter. In: Methods of soil analysis. 2nd ed., Part 2 ed., A. L. Page, R. H. Miller, and D. R. Keeney. eds. pp 539-579. Agronomy Monograph No. 9. Madison, WI: American Society of Agronomy. Odu C. T. I, Babalola O., Udo E.J., Ogunkunle A.O., Bakare T.A. and Adeoye G.O. 1986 Laboratory manual for agronomic studies in soil, plant and microbiology. $1^{\text {st }}$ ed.

Department of Agronomy, University of Ibadan, Ibadan, Nigeria. 83 pp.

Olsen S.R. and Sommers L.S. 1982.

Phosphorus. In Methods of Soil Analysis. $2^{\text {nd }}$ ed., Part 2 ed., A. L. Page, R. H. Miller, and D. R. Keeney. eds. pp 403-430. Agronomy Monograph No. 9. Madison, WI: American Society of Agronomy.

Pirkle J.L., Kanfmann R.B., Brody D.J., Hickman T., Gunter E.W and Paschal DC. 1998. Exposure of the U.S. population to lead, 1991-1994. Environmental Health

Perspectives. 106(11): 645-750.

Rainbow R. W. 2007. Integration of No-till and precision agriculture technologies and future challenges to conservation agriculture in Australia. In No-till farming systems. Special publication No. 3. Part 3 ed., T. Goddard., M. Zoebisch., Y. Gan, W. Ellis, A. Watson, and S. Sombatpanit eds. pp 223-246. World Association of Soil and Water Conservation, Beijing, China.

Udo E.J and Fayemi A.A.A. 1975. The effect of oil pollution on soil germination, growth and nutrient uptake of corn. J. of Environ. Quality. 4: 537- 540. 
Table 1a-Mean values of the soil properties $(0-15 \mathrm{~cm}$ depth) of different auto mechanic sites.

\begin{tabular}{|c|c|c|c|c|c|c|}
\hline Source & $\begin{array}{l}\mathrm{pH} \text { in } \\
\mathrm{H}_{2} \mathrm{O}\end{array}$ & Sand & $\begin{array}{l}\text { Silt } \\
\text { kg }^{-1}\end{array}$ & Clay & \multicolumn{2}{|c|}{$\mathrm{g} \mathrm{kg}^{-1}$} \\
\hline Ajebandele & 7.2 & 630 & 100 & 270 & 13.29 & $0.76 \mathrm{a}$ \\
\hline Oke-Ayo & 7.4 & 650 & 130 & 220 & 10.48 & $0.35 \mathrm{c}$ \\
\hline Modakeke & 8.3 & 610 & 120 & 270 & 18.96 & $0.86 \mathrm{a}$ \\
\hline Control & 6.8 & 630 & 130 & 240 & 12.86 & $0.64 \mathrm{~b}$ \\
\hline
\end{tabular}

Means with the same letter(s) are not significantly different by Duncan's Multiple Range Test at $\mathrm{P}$ $<0.05$

Table 1b-Mean values of the soil properties $(0-15 \mathrm{~cm}$ depth) of different auto mechanic sites.

\begin{tabular}{|c|c|c|c|c|c|c|}
\hline Site Source & $\begin{array}{c}\mathrm{P} \\
\mathrm{cmol} \mathrm{kg}^{-1}\end{array}$ & $\mathbf{K}$ & $\mathbf{F e}$ & $\mathrm{mg}_{1}^{\mathrm{Zn}}$ & $\mathbf{P b}$ & $\mathbf{H g}$ \\
\hline Ajebandele & $9.34 \mathrm{c}$ & $0.39 a$ & $1238.12 c$ & $18.10 \mathrm{c}$ & $1.30 \mathrm{~b}$ & $0.48 b$ \\
\hline Oke-Ayo & $14.76 \mathrm{a}$ & $0.04 \mathrm{c}$ & $1256.05 b$ & $20.18 b$ & $1.21 \mathrm{~b}$ & $0.48 b$ \\
\hline Modakeke & $15.74 \mathrm{a}$ & $0.06 \mathrm{c}$ & $1564.24 \mathrm{a}$ & $24.75 \mathrm{a}$ & $3.43 \mathrm{a}$ & $0.74 a$ \\
\hline Control & $11.90 \mathrm{~b}$ & $0.13 b$ & $37.50 \mathrm{~d}$ & $1.70 \mathrm{~d}$ & $0.15 c$ & $0.13 c$ \\
\hline
\end{tabular}

Means with the same letter(s) are not significantly different by Duncan's Multiple Range Test at $\mathrm{P}$ $<0.05$

Table 2a Mean values of the soil properties $(15-30 \mathrm{~cm}$ depth) of different auto mechanic sites.

\begin{tabular}{|c|c|c|c|c|c|c|}
\hline Site Source & $\begin{array}{l}\text { pH } \\
\text { in } \\
\mathrm{H}_{2} \mathrm{O}\end{array}$ & Sand & $\begin{array}{l}\text { Siltg } \\
\mathbf{k g}^{-1}\end{array}$ & $\begin{array}{l}\text { Cla } \\
\mathbf{y}\end{array}$ & \multicolumn{2}{|c|}{$\mathrm{gkg}^{-1}$} \\
\hline Ajebandele & 6.8 & 570 & 150 & 280 & 8.61 & $0.39 b$ \\
\hline Oke-Ayo & 7.0 & 600 & 150 & 250 & 7.07 & $0.20 \mathrm{~b}$ \\
\hline Modakeke & 8.1 & 520 & 180 & 300 & 9.74 & $0.53 \mathrm{a}$ \\
\hline Control & 6.3 & 600 & 140 & 260 & 7.38 & $0.30 \mathrm{~b}$ \\
\hline
\end{tabular}

Means with the same letter(s) are not significantly different by Duncan's Multiple Range Test at $\mathrm{P}$ $<0.05$

Table $2 b$ Mean values of the soil properties $(15-30 \mathrm{~cm}$ depth) of different auto mechanic sites.

\begin{tabular}{|c|c|c|c|c|c|c|}
\hline Site Source & $\begin{array}{l}\mathrm{P} \\
\mathrm{cmol} \mathrm{kg}^{-1}\end{array}$ & $\mathbf{K}$ & $\mathbf{F e}$ & $\begin{array}{c}\mathrm{Zn} \\
\mathrm{mg} \mathrm{kg}^{-1}\end{array}$ & $\mathbf{P b}$ & $\mathrm{Hg}$ \\
\hline Ajebandele & $9.36 \mathrm{c}$ & $0.26 \mathrm{a}$ & $983.55 b$ & $13.55 \mathrm{c}$ & $1.09 \mathrm{~b}$ & $0.43 b$ \\
\hline Oke-Ayo & $14.50 \mathrm{a}$ & $0.03 b$ & $1000.93 a$ & $17.46 \mathrm{~b}$ & $0.85 \mathrm{c}$ & $0.44 b$ \\
\hline Modakeke & $15.95 a$ & $0.05 b$ & $1002.37 \mathrm{a}$ & $23.25 \mathrm{a}$ & $2.66 \mathrm{a}$ & $0.68 \mathrm{a}$ \\
\hline Control & $11.86 \mathrm{~b}$ & $0.10 \mathrm{~b}$ & $3.57 \mathrm{c}$ & $0.56 \mathrm{~d}$ & $0.12 \mathrm{~d}$ & $0.12 \mathrm{c}$ \\
\hline
\end{tabular}

Means with the same letter(s) are not significantly different by Duncan's Multiple Range Test at $\mathrm{P}<$ 0.05

Table 3-Mean values of bioaccumulated $N, P$ and selected heavy metals in the shoots of maize

\begin{tabular}{|l|l|l|l|l|l|l|}
\hline Source & $\begin{array}{c}\mathbf{N} \\
\mathbf{g ~ k g}\end{array}$ & $\begin{array}{c}\mathbf{P} \\
\mathbf{c m o l ~ k g}\end{array}$ & $\mathbf{F e}$ & $\begin{array}{c}\mathbf{Z n} \\
\mathbf{m g} \mathbf{~ k g}^{-1}\end{array}$ & $\mathbf{P b}$ & $\mathbf{H g}$ \\
\hline Ajebandele & $2.64 \mathrm{~b}$ & $0.24 \mathrm{~b}$ & $152.86 \mathrm{~b}$ & $11.51 \mathrm{c}$ & $0.67 \mathrm{~b}$ & $0.20 \mathrm{~b}$ \\
Oke-Ayo & $2.46 \mathrm{~b}$ & $0.29 \mathrm{~b}$ & $126.56 \mathrm{c}$ & $13.60 \mathrm{~b}$ & $0.43 \mathrm{c}$ & $0.23 \mathrm{~b}$ \\
Modakeke & $2.33 \mathrm{~b}$ & $0.30 \mathrm{~b}$ & $179.03 \mathrm{a}$ & $14.83 \mathrm{a}$ & $2.17 \mathrm{a}$ & $0.46 \mathrm{a}$ \\
Control & $3.17 \mathrm{a}$ & $0.67 \mathrm{a}$ & $23.69 \mathrm{~d}$ & $1.47 \mathrm{~d}$ & $0.10 \mathrm{~d}$ & $0.05 \mathrm{c}$ \\
\hline
\end{tabular}

Means with the same letter(s) are not significantly different by Duncan's Multiple Range Test at $\mathrm{P}<$ 0.05 